\title{
A missiological reflection on African ecclesiology
}

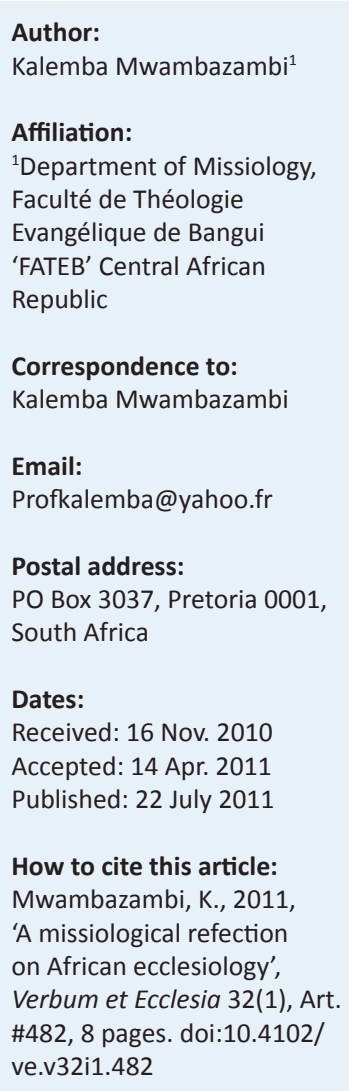

(C) 2011. The Authors. Licensee: OpenJournals Publishing. This work is licensed under the Creative Commons Attribution License.
The 21st century challenges African Protestant missiologists to push the boundaries of African Protestant ecclesiology beyond the current status quo by 'isolating the crucial issues, mapping out the challenges and identifying past and current traps' (Maluleke 1996:3). As African theologians propose, African ecclesiology represents two major concerns for the Christian mission in Africa: firstly, to Africanise the Christian message, and secondly, to contextualise the liturgies that have prompted this need for Africanisation in order to dissociate the African tradition from faith in Christ. Indeed, it is necessary to read the Gospel with renewed attention to the comments of the Fathers of the Church and yet be indifferent to the strategic directives of Catholic ecclesiology. This article set out to analyse and demonstrate the contribution of African ecclesiology to Protestantism in order to gain a better understanding of the role of the Church today. The critical-theological research method was used.

\section{Introduction}

African Protestant ecclesiology does not encompass an easily captured and objective body of ideas, practices or values that can be serenely contemplated and analysed. It is more like an interior structural force that is best understood from the vantage point of contemporary African existence.

This structuring force places the entire African past within the dynamic construct of African identity, African cultures and African traditions, all of which are being assailed with the influence of globalisation.

Globalisation is having an equally decisive impact upon the religious universe of African civilizations; it has affected the relationship between the Protestant and Catholic churches in Africa, with implications for the issues of tradition and modernity in the African Protestant ecclesiology and how the Gospel can, through the African churches, prepare a new civilisation which, as Bediako (1990:85) said, 'will allow us to live in the age of Africa's faith and confidence in God'. Thus, the influence of Pentecostal, charismatic ecclesiology, specifically the growing influence of Word-faith theology on African missional ecclesiology and their hermeneutic cannot be ignored.

This article will ponder the missiological concerns of the Protestant churches in Africa and will try to respond to the question: what does African Protestant ecclesiology contribute to our understanding of the role of the Protestant and African Independent Churches (AICs) in Africa at present?

Ecclesiology grows out of missiology and at the same time, forms a dimension of missiology. Christian missions, as the priority of missiologists, missionaries, theologians and Christians, are the starting point of any missiological reflection. A glance at African Protestant ecclesiology demonstrates that 'Africa plunged into the new world order not as a stable continent, but as a region receding into ethnic fragmentation and economic disintegration ...' (Mugambi 1995:207). However, the churches in Africa are in a unique position to give concrete social content to the dream of a new African society, because they can potentially free the peoples of the weaknesses and harmful practices of certain cultural traditions and release them from the many aspects of life that fail to meet African hopes (Pongo 2005:17). It is clear that most of protestant ecclesiology in Africa needs to be revisited and recontextualised, as it has failed in many areas of church life.

Any profound reflection upon the Christian mission and the church's role in the transformation of Africa, must seriously engage with the various African ecclesiologies of the 21st century to develop an empathetic Christian mission model that inspires and transforms the existing models of Christian mission, the tension between African traditional church leaders and the Protestant 
church. It will be useful to analyse their relevance and missions, in order to lead African theologians toward an African ecclesiologies that can address the issues mentioned previously.

\section{Research background and development}

Contemporary missiology is an independent science that has filled the vacuum left by the two classical and inherited ecclesiologies, namely, the Protestant and the Catholic ecclesiologies (Solomon 2001:55). The Protestant ecclesiology dealt with the nature of the church, its government and officers, sacraments-mysterium and the relationship of the Church with the State. In terms of mission, the Protestant ecclesiology also differs from the Catholic tradition. According to the 'Apostles' Creed, the four traditional ecclesiological characteristics of the church are: One, Holy, Catholic and Apostolic' (Saayman 2009:290); but Pesch (1974:584) observes that 'Catholic ecclesiology is based intensively upon the theology of Thomas Aquinas who adopted Aristotle's approach'. For the Catholic Church, the Pope is seen as the apostolic successor and the sacraments take precedence over mission, this is ecclesiology without missiology.

The central characteristics of the Protestant churches are their focus on correct doctrine, the right ministry of sacraments and the right application of discipline. Protestant churches focus on 'missionary societies, but not on church mission' (Pongo 2005:17), whereas the AICs are missionary churches, but lack ecclesiology, because they are less in line with the one, holy, catholic and apostolic concept of the church.

The ecclesiological nature of the Catholic Church, therefore, entailed confirming the necessity of the succession of St Peter (something that Protestants could no longer claim) and defined the true church with reference to the Pope (or his representative, the Bishop). The very nature of the (Reformed) Protestant churches may be discerned from the proclamation of the Word, the maintenance of discipline and the right ministry of the sacraments (which, they claimed, were lacking amongst the Catholics). The extroverts in the Catholic Church:

generally found their home in the missionary religious orders, and those in the Protestant churches found their home in the mission societies; neither group significantly influenced the official ecclesiological thinking.

(Saayman 2009:290)

Both the Catholic and Protestant churches were largely untouched by the enormous release of missionary activity at the time and whilst mission was certainly a part of the life of the church, it remained an appendix to the true business of the church, which had to do with maintaining the survival of the existing institution. The construction of 'a truly missionary ecclesiology, therefore, remained a future responsibility' (Saayman 2009:291).
The model of mission proposed by the Vatican Council II through Ad Gentes [To the nations] and presented by John Paul II in his encyclical Redemptoris Missio [Mission of the Redeemer], has some very interesting and timely things to say to Protestant ecclesiology. This encyclical deals with missiology in the present Africa. Catholic ecclesiology is influencing African Protestant ecclesiology through three important characteristics of this modernised model of Christian mission: ecumenism, inter-religious dialogue and partnership with all human and organisational resources, in order to reach the whole world with the Gospel (Solomon 2001:41). Analysis demonstrates that, missiologically, the Catholic model of Christian mission is based on a solid and coherent ecclesiology compared to Protestant ecclesiology, whereas each Protestant denomination has its own doctrine and vision. The advantage of Catholic ecclesiology is recognised in the fact that every missionary initiative is under the control and sanction of the Church. Every missionary religious order must be loyal to the hierarchy, especially to the bishop at local church level. The chapter entitled de Activitate Missionali Ecclesiae [Missionary activity of the church] of the Vatican Council II is a most helpful discourse on church mission (Solomon 2001:41).

In Protestant ecclesiology, each group steers only its own understanding of mission and analysis reveals the inevitable ambiguities that have grown up in the praxis of Protestant Christian mission, unlike the Catholic ecclesiology, where the inclusion of mission results in a consistent approach. This means that not only missionaries, but also the head of the Christian mission submits to the bishop of a particular church. Even from the biblical and historical perspective, Christian mission and the church are strongly linked to each other. According to Acts 2, 'the Great Commission' of the Christian mission was inaugurated on the day of Pentecost and it was 'given to the apostles before the birth of the Church' (Solomon 2001:16). The disciples of Christ received the command to 'make disciples of all nations' (Mt 28:19) and they started this missionary work on the day of Pentecost itself, when Peter preached to a gathering of people from many nations and languages. Griffiths (1988:1) comments that 'the church and Christian mission have a chicken-andegg relationship'.

In Protestant ecclesiology, the church is presented as a community of brothers and sisters, God's people, a spiritual family. Pongo (2005:29) underlines that 'the organization and functioning of the Church are best understood in the light of the traditional family, and its hierarchy has been very largely Africanized'. In fact, the membership of churches in Africa is growing fast. According to some theological and ecclesiological observers, it 'seems as if the centre of gravity of Christianity may indeed be moving from Europe to Africa' (Solomon 2001:9). Walls (1998) points out:

It is widely recognized that there has occurred within the present century a demographic shift in the centre of the Christian world, which means that more that half of the world's Christians live in Africa ... The Christianity typical of the twenty-first century 
will be shaped by the events and processes that take place in the southern continents, and above all by those that take place in Africa.

(Walls 1998:2)

However, in the missiological context of today, one need's to take a deeper look and to clarify why there are those who agree with the definitive conclusion Walls draws from the demographic statistics. Solomon (2001) points out that:

[It] is clearly known that the relationships between indigenous leaders and missionaries are not the best, mostly, indigenous churches and mission agencies have no arena for discussion and sharing, therefore the malaise between church leaders and missionaries persists.

(Solomon 2001:10)

This is also because some Catholic and Protestant missionaries consider the indigenous churches as syncretism.

Saayman (1998:1) observes that in the Catholic Church, 'most mission agencies still use the nineteenth century missiology based on a hierarchy of assumptions from western cultural and moral superiority'. This hierarchy seems to survive amongst all missionaries today, but the principal characteristics of African ecclesiologies differ from that of the Catholic and Protestant churches. African churches are less interested in doctrine and more interested by the movement of the Holy Spirit and likewise, they are not interested in the manner of pastoral dressing from the Catholic Church or the liturgical motive. The AICs believe in bringing about a positive transformation for the African people without Catholic and Protestant ritual liturgy and the use of African hymns in their worship services. The churches proclaimed their autonomy from the old missions and affirmed their African identity. Most AICs are also stressing glorious uniforms and hours of chanting, marching and other African rituals.

\section{The African context for church and mission today}

The research question here is: what does Africa look like today and what does this require of church and mission? So, a missiological survey of Catholic, Protestant and AICs for the mission of the church in the current African community will prove useful, because these three 'building sites' are a current reminder to African missiologists to reconsider the mission of the church and the evangelisation of Africa.

Obviously, the church can motivate Africans to live and act in the knowledge that the reconstruction of Africa is reliant upon the creative power of Africans to develop themselves; therefore, the aim is to consolidate the spiritual dimension of Africa and its bond with the various African religious forces with the Protestant ecclesiology. This will renew social practices amongst Africans, so that their collective life can focus on the success of the spiritual and physical reinvention and rebirth of Africa within the larger world order. Indeed, freeing Africa from poverty, violence, different conflicts and HIV and AIDS must be a primary concern of African missiologists and leaders who care about the well-being of the continent.
African ecclesiologies help African people by showing them that liberal globalisation is not the only way to improve North-South relations or to relieve the poverty of countries known as underdeveloped or under equipped. Missiologists are called to invest their efforts:

- in projects for social innovation in the pursuit of a new social economy

- in social spirituality and intelligence

- in interdependent and popular values that rest on close cooperation

- in promoting an equal and balanced share of the community's products

- in collective acts of reconstruction and building up.

A communal economy places the human person at the centre of socio-economic and political development and requires a new mentality that establishes human relations on the basis of consensus and joint action. Social progress and socioeconomic development are so desperately needed and it is through the discovery of their true identity that people will find their spirits and their creativity renewed and will find original solutions to their problems and no doubt, those of others too.

As Mudimbé (1980:563) says, 'there is necessity in our social, economic and cultural structures, to make a choice place for our creative subjects and to appeal to mass creativity'. However, it is difficult at present to supply a single and total vision, which would give an account of what Africans are supposed to know about the structure of globalisation, because the majority of Africans have tended to trivialise globalisation; this is apparent in the everyday speech of the ordinary people. This indifferent attitude to globalisation can be regarded by African missiologists as a calamity for the African continent, especially in terms of the domination of the poor by the rich. Such a cultural misunderstanding leads Mudimbé (1980) to observe:

Africa currently misses cultural bases for good understanding and mastering of the world problems, of the true cause of our African dependence, of the true obstacle to our progress economic, social, cultural and nature, it seems, of a human nature; we would even say of a philosophical and moral nature.

(Mudimbé 1980:565)

Indeed, globalisation is a product of the developed world, without reference to the will of God, which views Africans as consumers (Pongo 2005:29). Kä Mana (2005a:233) notes that the idea that globalisation is 'an untamable externality' plants in the very imagination of Africans a sense 'of powerlessness and infantilisation', which makes them vulnerable to a world more than willing to dominate them. It is important that they see themselves as actors in a destiny, whose purpose 'is to build the true stature of creative historical subjects'. So, the intention of African ecclesiology in the present context is to incarnate the emergence of a new missionary consciousness in African Christianity, a consciousness directed not only towards the construction of a new African society, but also towards a world project and a social transformation for all based on fundamental values of Christian faith. Indeed, the current state of the world relates not only to African 
ecclesiology, but to all Africans, because it prevents the transformation of the current world order. However, even if Africa were to hold her breath in hope, Kä Mana (2005a) specifies that:

The role of Africa and her churches in such a world, is to put at the heart of the reflection, the research for the conditions for an overall fight against the mortal sedimentation of mentalities in our current society, against the spirit of destruction of human beings and disorganizations of the communities, against the socio-economic madness which has been globalized in our time: the great tragedy of a deaf and blind global system facing the challenges of the future and deep searches for the humanity.

(Kä Mana 2005a:223)

In fact, it is a reign of nothing and a race to crushing domination that African missiologists need to avert and denounce. African ecclesiology has a key role to play in deflecting a destructive and anti-social globalisation without God and its main role is to incarnate and to diffuse the divine truths, which reveal to humans the essential values of life and their worth as human beings.

Africa needs to be less complacent about the dangers of globalisation which, directly or indirectly, robs Africans of their consciences and creative historical subjects of their energies; however, globalisation is a human creation and nothing that is human can ever be strange to Africa. There is a need to reconsider globalisation, which integrates Africans into the total global destiny and to consider that all the peoples of the world should together build a common house for all, a house built according to spiritual ethics. Life being complex, the winners of today can become the losers of tomorrow and the losers of yesterday may become the winners of today.

That requires a new mentality, unity and the conscious refusal to be losers. So, the African missiologists can, through African ecclesiology, work to integrate Christian ethics into the worldwide economy in the form of the great principle of community well-being. It is from the perspective of values and direction that African Christianity has a great role to play to train upright people, able to combine socio-economic realism and cultural-political combat tempered with a great concern for humanity. Indeed, the transformation of African society can be made possible through an academic and popular ecclesiology. The church of Africa can, however, by her missionary dynamism, turn the world upside down through in-depth evangelisation and a new form of Christian ethics devised according to the will of God.

\section{Important characteristics of African ecclesiologies}

The purpose of this section is to provide an overview of the important characteristics of African ecclesiologies. The section is divided into five parts: the first part will focus on the centrality of Christ, the second on the renewal of inherited liturgical practices, the third on ecclesiologies based on felt needs, the fourth on ecclesiological impulses from the AICs and the last one on leadership issues in AICs.

\section{Christ centricity}

One of the important characteristics of African ecclesiologies is the centrality of Christ and the Bible. This is not to suggest that the Bible is not central to other formulations of the Christian church, but it is a generalised truth that every branch of the African church holds scripture as the supreme rule of faith and central to their understanding of God's revelation in Christ. West (1995:195) confirms that 'AIC church leaders in speaking for ourselves affirm their belief in the Bible's absolute authority'. One of the important defining qualities of African ecclesiologies is the christocentric nature of their doctrine and worship style. The christocentrism of African ecclesiologies affirms 'Jesus as African ancestor, as the centre, as the point of departure' (Pongo 2005:29). Also, the attraction of the Pentecostal-type AIC hermeneutics for African people is that probably above all other considerations, these churches are believed to provide biblical answers for 'this worldly' needs like sickness, poverty, hunger, oppression, unemployment, loneliness, evil spirits and sorcery; therefore, in Pentecostal-type AICs, the experience of the Spirit becomes an essential and perhaps the most important key in the hermeneutical process (Oduro 2008:90). As regards ecclesial method, this has led to an over-reliance on notions of orthodoxy in their doctrinal and missiological practices.

\section{Renewal of inherited liturgical practices}

One of the strengths of African ecclesiologies is their ability to embody another world within their liturgical practices and their pneumatological perspectives. The liturgical traditions derived from methods of the developed world are more common in the traditional churches, whilst African practices based on indigenous methods are utilised by the African churches (Pongo 2005:31). For example, the AICs use baptism in a completely new way to reintegrate witches into the community. Pneumatologically, African people are able to play with reality by means of an imminent realisation of the Holy Spirit in worship, in order to remake their social realities. Symbol and African ritual have always formed the centrepiece of African ecclesiology.

Furthermore, African ecclesiology is a liberation ecclesiology and transforms traditional ecclesiologies in the African context. African preaching remains the definitive feature and liturgical heart of African worship. Bantu prophets or indigenous clergy are another characteristic of African ecclesiology. Those several ecclesiologies began to construct an explicit Afrocentric conception of the Christian faith. The African ecclesiology has been perceived as the key social, political, educational and organisational entity in the collective and communitarian experience of African people.

\section{Ecclesiologies based on felt needs}

The African ecclesiological method begins with African existential experiences, but not with historic mandates and was often born of abstract philosophical musings as to the nature of the body of Christ. There remains a powerful tradition of the oneness of God, which does not recognise 
the allegedly speculative Trinitarian formulation of the historic church. The AICs does not live in mutuality and interdependence with other missionary churches throughout the world. The African church can be characterised 'as truly evangelical in the sense in which the term was used before ecumenical and evangelical polarisation narrowed the definition' (Saayman 2000:14). African ecclesiologies of the 21st century could develop a model of Christian mission that inspires and transforms.

Africa needs an academic and popular ecclesiology for its positive total transformation and its real spiritual and physical reconstruction. A reconsideration of Protestant ecclesiology is very relevant for the African ecclesiologies, as it can examine the following points:

- topicality

- medium

- context

- concerns of the moment

- culture and tradition

- the questioning of African centres of interest in accordance with the Gospel brought by Jesus.

The perpetuation of the old paradigm is one reason why the AICs and other movements have successfully planted so many churches, even without an ecclesiological model. They share several characteristics, but in some important respects they are very different from each other, so it would not be correct to put them all in one category. Indeed, there are a variety of ecclesiologies in Protestant circles and they interpret their church missions differently.

\section{Ecclesiological impulses from African Independent Churches}

At present, in French-speaking Africa (Burundi, Cameroon, Central Africa, Congo Brazzaville, Democratic Republic of Congo, Gabon, Rwanda, etc.), in English-speaking Africa (Ghana, Kenya, South Africa, Uganda, Zambia, Zimbabwe, etc.) and in Portuguese-speaking Africa (Angola, Mozambique, etc.), the Catholic and Protestant churches constitute a force acting within the Christian family, but they are not the only religious forces to occupy the current social space. This is because different dynamics exist, which fertilise the people's imaginations and structure their spiritual perception of the destiny of Africans. These dynamics are an integral part of African life and are made up of the Churches, sects and new spiritualities. Mwene (1990) states that:

African Messianic communities function nowadays as particular groupings within various African societies which are in the temporary situation of the old forms of the economic and social organizations to the new ones introduced by colonization.

(Mwene 1990:83)

These AICs and sects are places that try to bring symbolic or concrete solutions to transitional situations where people have the shared experience of living with the consequences of colonisation and decolonisation. However, the lack of appropriate ecclesiology appears at various levels of the AICs and implies that most indigenous churches have a missionary vision without ecclesiology. They are presented as high places for the satisfaction of the spiritual needs of their members. So, the partial failure of Protestant, Catholic and evangelical churches in Africa to provide adequate answers to the spiritual and physical needs of their members has obviously contributed to the creation of new spiritual communities that do meet the aspirations of African believers and consequently, encourage the conversion of their members. It's clear that the AICs are doing 'mission in an African way' and that the mainline churches can learn from them. They are obviously meeting the real needs of people in the African context at the grassroots level. They are drawing people to God by contextualising and inculturating the Gospel for African people. Their approach is a significant contribution to the proper understanding of Christian mission and can no longer be ignored (Oduro 2008:49).

\section{Leadership issues in African Independent Churches}

However, on examining the theology of AIC, it seems necessary to give special attention to their Christology and African messianism for, as Hebga (1990:80) points out, 'too often the charismatic leader enjoys a position of ambiguity that competes with that of Christ'. These church leaders are gladly called prophet, Black Messiah, visionary, president and initiator. A figure like Isaiah Shembe, for example, bluntly replaced Christ even in the doxology of the Trinity and set himself up in the role of saviour of the White people. By contrast, others, like Simon Kimbangu, 'rejected any claims to personal divinity and proclaimed themselves as messengers of God and liberator of Black people' (Pongo 2005:38).

Indeed, a missiological glance at the current situation of the AICs reveals two important phenomena, which currently characterise their consciousness of their mission. So, as Solomon (2001:44) warns, it would not be correct to put them all in one category. The first phenomenon is a displacement of the centre of gravity. This is explained by Kä Mana (2005b) as:

the passage from a state of the communities of popular protest against a certain spirit of the society and institutionalized churches, coming from the establishment of the Western missionaries ...

(Kä Mana 2005b:31)

The second phenomenon relates to progressive disappearance, without compliance, of the inferiority complex that these AICs and the sects suffered vis-à-vis the powerful presence of Catholicism or historical Protestantism. The disappearance of this inferiority complex has, as a corollary, the commitment of the Independent Churches to social, political and economic ambitions. This was precisely the case of the Kimbanguist church, which has parishes, schools, universities and polyclinics in several countries of the world. However, the AICs seem to commonly experience a syndrome of inner divisions. They often experience schisms over internal struggles for power and of the personal ambitions and egoistic interests of their leaders in the race for material advantages. 
The African spiritual identity of these AICs is strongly anchored in the ministries of miraculous healing, spiritual combat against evil spirits, forces of sorcery and fetishism. In fact, the mushrooming of sects and new religious movements in English, French and Portuguese-speaking Africa can be decreased if the Catholic, Evangelic and Protestant movements would decide to work together (Kalemba 2009:236). The true enemy of the Christian mission is the harmful effect caused by the way that these spiritual communities treat each other as sects, according to a principle of exclusion. The traditional churches do the same, and hence a sort of denominational Babelisation occurs. The reorganisation, reorientation and redynamisation of the African independent and traditional churches through a reconsidered African ecclesiology will prove to be relevant; therefore, missiologists can, through a reconsidered African ecclesiology, learn how to combat ambiguous spiritualism, the religiosity of fear, the various theories that paralyse intelligence and sever the rational springs of spirituality, spiritual blindness and the reign of absurdity and the ignorance that many Africans display as far as their Christian life is concerned.

\section{A new approach to mission}

The current African context is favourable for a profound Christian mission that makes the training of missionaries especially important. They will not be able to cope with or overcome dangerous sects and new misleading spiritual movements if they are not well-trained and well-prepared spiritually and academically for their missionary cause. So, African ecclesiology can develop its capacity for intervention with the populations in a way that better meets their needs. Kä Mana (2005b:13) believes it is necessary to ignite the 'imagination, breathe creative dynamics, [and] innovate African missionary fields with in-depth work and evangelization'. Obviously, if Africans are informed and formed as sons and daughters of the Kingdom of God, they will represent a truly great and vital force for the positive transformation and rebuilding of the African continent.

The AICs played a big role in planting new churches in remote places, but compared to the Protestant and Catholic ecclesiologies, they lack an ecclesiastical tradition and they have to face a number of ecclesiological issues. They have no clear mission model, but their contribution to extending the Kingdom of God is excellent and many more churches will be planted in the next few years; however, these new churches will surely face the same problems as the Pentecostal churches in Africa. There is no model of church organisation or order, no clear vision for the actual churches planted and no solid theological discourse. It is clear that most of Protestant ecclesiology in Africa needs to be revisited and recontextualised, as it has failed in many areas of church life. Solomon (2001) affirms that:

for the last three decades, the number of Christians in Africa has grown dramatically. So, for example, Christianity in Africa has been enriched with more than 10,000 African Independent Churches.
Since the beginning of the 1990s, a significant number of African neo-Pentecostal churches have also emerged. AICs are exciting and replacing the Christianity of the missionaries with a deeper and more genuine Christianity (Oduro 2008:90). The culture of the developed world is, by nature, a culture of repetition (Pongo 2005:34). It provides and imposes the models of the dominant countries: the ideological, political, economical and religious models that are implied in the concept of globalisation. This culture also takes part in the generalised development of the African countries, by reproducing the capitalism of the developed world (Pongo 2005:36). This is why the church of Africa has a great mission to transform the world's vision of Africa through in-depth re-evangelisation. This Christian and African mission for the re-evangelisation of Africa might seem to lack originality, but it is real. Obviously, evangelisation is one of the main missions of the church in Africa and its force of conversion can transform Africa through Christ and the acts of faith.

However, the church in Africa should reconsider today the direction of its presence in the world and rethink its prophetic mission for Africa, because excessive political and economic centralisation, techno-bureaucratic influence, massive acculturation and illiteracy are still serious obstacles to freedom and the creative richness of the African people. At present, the dogma of the last judgment that characterised the Christian faith in Africa is disappearing to the benefit of the technological revolution and globalisation. Kä Mana (2005a) writes:

I have the feeling that nobody really believes that every human has to account for everything they did to God one day. The life that we are leading in the current world is a life without the horizon of the God who judges.

(Kä Mana 2005a:157)

It is the present life, here and now, of which the church speaks when it refers to the Holy Scriptures about the last judgment, whilst most African people think of it as something of an illusion or a figure of speech. In Africa, the main problem lies in the effects and impact of what has been announced by the Catholic and Protestant church about the reality of the challenges with which Africa is confronted:

- miseries

- political and military conflicts

- divisions

- mediocrities

- sterilities

- despairs

- catastrophes

- xenophobia

- derelictions

- jealousies

- capacity for destruction

- powers of death.

Christianity in the Democratic Republic of Congo has been socially sterile and responded poorly to the concrete questions and existential concerns of the Congolese. Indeed, Christianity in the Democratic Republic of Congo, the cradle of the inculturation in African theology, has unfolded with 
an admirable spiritual exaltation that has no equal, but its practical sterility remains. Kä Mana (2005a) points out that:

There are, of course, some exceptions, but the general situation is not perfect as regards educational structures and the dynamics of the formation of the creative forces in the African society, and the health catastrophe.

(Kä Mana 2005a:242)

Obviously, people of Africa cannot claim to control their destiny if they do not have a good social spirituality, social intelligence and good educational and medical policies. In fact, in the present African situation, it is important to incarnate the relations between Christian mission, church and society. Thus, African missiologists should beware of the present reality and stop thinking that the church in Africa can continue to function according to the model of evangelisation of the worthy missionaries from the developed world and their theological vision of social works. In fact, Protestant ecclesiology in Africa can, in its present context, seek to build a new system of spiritual capital that the Christian mission can bring into the world with an evangelic fruitfulness and credibility because, presently, the majority of God's people in Africa live in disorder and have failed to establish the relationship between their Christian faith and their engagements with the world. For this reason, the African church has a mission to take an active part in the new re-evangelisation of Africa, to bring relief from the inhumanities of capitalist misdeeds based on egotistic and destructive interests. A deep reform of Protestant ecclesiology is necessary. Unfortunately, the Protestant church of Frenchspeaking Africa, especially of the Democratic Republic of Congo, encourages its members to pray a great deal, but does not make them reflect sufficiently on themselves or make realistic commitments to rebuild a new community. Africa must be aware that the serious problems of humanity are also hers and that her people have much to contribute to solving them from the well-spring of their creative genius; in the global setting, Africa can suggest horizons of new life to all humanity in all the essential fields for a better future. Maluleke (2005:197) states that 'mission needs to be rethought as the relation between a particular understanding of church and a particular understanding of the world, where both are governed by justice/right relations'.

The church is, indeed, missionary by its very nature and this is embodied in a truly missionary ecclesiology. The church and mission have to work together, because it is difficult for any group of Christians to survive without forming ecclesia [community] and ecclesia cannot survive without mission. The link between church and mission are central to the concept of Missio Dei [the mission of God]. Any church is missionary by their nature, although 'mission and church are regarded as two separate structures which Christians had to link together in some way' (Saayman 2000:19). The process and progress from church to mission to church should 'rather be seen as cyclical, and specifically as an ascending, never-ending spiral' (Saayman 2000:20). Churches, equally, need to develop an adequate missionary ecclesiology for today. It is correct to say that there is a greater interaction between church and mission owing to the urgency of the ecclesiological problem in Christian mission. The missionary church lives in mutuality and interdependence with other missionary churches throughout the world. After Tambaram, it would be 'impossible ever again to speak about mission without speaking simultaneously about the church - and vice versa' (Saayman 2009:288). Christian Mission has its origin in God, who is the source. The church is the result. The Christian mission is the first mission 'from God - the communication to all men of God's love, as Jesus Christ who showed attention even to the smallest, in the strength and the fellowship of the Holy Spirit' (Bosch 1995:10). Christian mission highlights the dynamic relationship between God and the world, as first reported in the covenant with Israel and then, finally, in the coming, life, death, resurrection and exaltation of Jesus Christ. On the theological level, we cannot establish the Christian mission without continually referring to the fundamentals of the faith: God's self in Jesus Christ.

God is the first missionary, as expressed in the missio Dei [the mission of God]. Christian mission means spreading the Gospel message and extension of the church. Obedience to the mission imperative of Matthew 28:18-20 is an act of faith that is based on the supreme command of Jesus Christ. Evangelisation and church planting are the essential dimensions of the mission, together with the proclamation of salvation in Christ to all who believe:

To call people to repentance and conversion, to announce the forgiveness of sins, to invite all to become living members of the community of Christ's earthly life and to try to serve others through the power of the Holy Spirit.

(Bosch 1995:22)

Christian mission is also a ministry with many facets:

- witness

- service

- justice

- healing and reconciliation

- the liberation of the oppressed

- the search for peace

- evangelism

- fellowship

- church planting

- the eschatological motive.

Moreover, it is necessary that the church of Africa send out African missionaries deeply committed to new ways of evangelisation and re-evangelisation.

African Christians who presently reside in Europe and America, for example, can also be used as an effective bridgehead for the true in-depth conversion of Europeans and Americans to the true meaning of the Christological word, because 'Europe, especially France, is renouncing her spiritual source while refusing to permit public signs and references to Christianity in her constitution and her community life' (Pongo 2005:81). The church of Africa thus, has a heavy responsibility of going everywhere, in accordance with the supreme order of Jesus, to make 'disciples' of Christ 
(Mt 28:19-20); however, this mission can only be possible if Africans can be self-critical and transform themselves first, before thinking to transform other continents.

The best understanding of the church's mission today is that each church must do what it can to extend the Kingdom of God and to make the positive transformation of African societies possible. African theologians should propose another typology, one which takes into account more recent developments, such as the proliferation of so many new churches. Solomon (2001:64) states that this new typology considers the daily life and practice of each church rather than official theology. It deals mainly with spirituality and with the way faith is expressed corporately rather than the content of faith'.

\section{Conclusion}

Within Protestant ecclesiology, unity in missionary work remains a challenge, in spite of the common roots and characteristics that the African Protestant churches share. This is also because the attachment to a denomination prevails over the quest for unity and the legacy received from the former paradigm, the paradigm of the 19th century, proves to be an obstacle to church unity. Nevertheless, the main reason for disunity is that each Protestant denomination has a better knowledge of its own inherited paradigm than the paradigm of early Christianity. Moreover, 'African churches have riches to give and to receive from one another, and a better understanding and accomplishment of the Missio Dei' (Solomon 2001:69).

Catholic ecclesiology may help other churches understand the importance of a solid model of mission and the sense of belonging to the universal church. Protestant ecclesiology can encourage other churches to consider the centrality of scripture and the priority of the re-evangelisation of Africa and can also help Christians understand the reality of spiritual warfare today in Africa, given that evangelism and Christian mission are basically a spiritual battle. The AICs can help to rethink the place of the Word of God in Africa. It is necessary that the African people consult biblical history when rethinking the reconstruction of Africa. This fundamental perspective can lead the African missiologists to rediscover the energy of the African monks and the mystical consciousness in the socio-political, cultural and economic structuring of power in African society.

However, in the present context of African ecclesiologies, it is essential that missiologists examine these perspectives and their Christological incidences. African missiologists can also develop, as of now, a deep-rooted Christianity that offers African religions, a wealth of vital spiritual fruitfulness. It is for this reason that the African ecclesiologies can put God at the centre of this process, in a kind of global pastoral and social transformation. So, it is useful to rebuild, as of now, an African spirituality of cooperation such as existed before the African colonisation (Tutsis and Hutus, Bantu and Bushmen etc).
African missiologists can thus promote a transverse spirituality and render it comprehensible. The different ecclesiologies can help churches to play their role and make a significant impact on African society. They also need to take into account the relationship between culture and mission. A global ecclesiology includes all churches in this, because this global ecclesiology can help church leaders develop a mutual understanding of mission and better cooperation towards the realisation of the Kingdom of God. The best ecclesiology for Africa at present can be inclusive and reinterpret the basic missiological data, such as the attributes of the church, biblical revelation, the tasks before the church, the future of the church and to understand that the church is God's enterprise and not a human one.

\section{References}

Bediako, K., 1990, Jesus in African Culture: A Chanaan Perspective, Asempa, Accra, Ghana.

Bosch, D.J., 1995, Dynamique de la mission chrétienne. Histoire et avenir des modèles missionnaires [Transforming Mission. Paradigm shifts in theology of mission], Karthala, Lomé.

Bosch, D.J., 1991, Transforming Mission. Paradigm shifts in theology of mission, Orbis, Maryknoll.

Gort, J., 1980, World Missionary Conference: Melbourne, May 1980. An Historical and Missiological interpretation, Free University, Amsterdam.

Griffiths, M., 1988, 'Ecclesiology and mission: The Henry Martyn Lecture 1988', unpublished paper.

Hebga, M., 1990, Interpellation des mouvements mystiques' [Hermeneutic of mystical movements], FCK, Kinshasa.

Kalemba, M., 2009, 'Un regard Missiologique sur la Théologie de Libération SudAfricaine' [Missiological looking on liberation theology of South Africa], Swedish Missiological Themes 97(2), 229-244.

Kä Mana, K., 2005a, La mission de L'église africaine [African church mission]', Cipro, Yaoundé.

Kä Mana, K., 2005b, A coeur ouvert [A heart open], Clé-Cipcré, Yaoundé.

Maluleke, T.S., 2005, 'The DOV and Challenges before Us: Ten Concluding Reflections', in M. Jacques (ed.), Come Holy Spirit, heal and reconcile, pp. 195-201, WCC, Geneva.

Maluleke, T.S., 1996, 'Black and African Theologies in the New World Order: A time to drink from our own wells', Journal of Theology for Southern Africa 96 (November), 3-19.

Mudimbé, V.Y., 1980, La dépendance de l'Afrique et les moyens d'y remedier [Dependence of Africa and ways to remedy it], erger-Levrault, Paris.

Mugambi, J.N.K., 1995, From liberation to reconstruction: African Christian theology after the Cold War, East African Educational Publishers, Nairobi.

Mwene, B., 1990, Les perspectives spiritualistes dans les communautés messianiques africaines, [Prospects spiritualists in Messianic congregations in Africa], CERA, africaines,
Kinshasa.

Oduro, T., 2008, Mission in an African Way: A practical introduction to African Instituted churches and their sense of mission, Bible Media and Christian Literature Fund, Wellington.

Pesch, O.H., 1974, 'Paul as Professor of theology: The image of the Apostle in St. Thomas theology', Thomist 38(1), 584-605.

Pongo, M., 2005, La théologie en Afrique et ses implications [Theology in Africa and its implications], Ngumu, Mbuji-Mayi.

Saayman, W., 2009, 'Missionary ecclesiology: A perspective from history', Studia Historiae Ecclesiasticae 35(2), 287-300.

Saayman, W., 2000, 'Missionary by its very nature...: A time to take stock', Missionalia 28(1), 4-22.

Saayman, W., 1998, 'Missiology in the theological faculty: A view from South Africa', Mission Studies 15(1), 29

Solomon, A., 2001, 'The missiological dimensions of African ecclesiology', D.Th. thesis, Department of Missiology, University of South Africa, South Africa.

Walls, A., 1998, 'Africa in Christian history: Retrospect and prospect', Journal of African Christian Thought 1(1), 2-15.

West, G., 1995, Biblical hermeneutics of liberation, Cluster Publications, Pietermaritzburg. 